\title{
POSSIBILITIES OF USING INNOVATIVE SOURCES OF INFORMATION ON REAL ESTATE IN THE SPATIAL DATA COLLECTION PROCESS
}

\author{
Anita Kwartnik-Pruc, PhD \\ AGH University of Science and Technology \\ e-mail:akwart@agh.edu.pl
}

\begin{abstract}
The register of land and buildings is an essential source of information on real estate. The use of cadastral data in land management is manifold, starting from spatial planning, through the calculation of taxes, the designation of real estate in land and mortgage registers, and finally, in real estate management. The accuracy of information from public records, i.e. the register of land and buildings, obtained by entities managing property has a direct impact on the correctness of the conducted processes of land management. Data necessary to determine the position of boundaries of cadastral parcels are taken from surveying documentation accepted into the national geodetic and cartographic resource database. If there is no such documentation, or the data contained therein are not reliable, information on the boundaries of cadastral parcels are obtained by means of field or photogrammetric surveys, preceded by the determination of the course of these boundaries.

The present article analyzes the requirements of legislature regarding real estate data contained in the register of land and buildings. The possibility of capturing such information using an innovative method of laser scanning was also identified and tested. The object of the research was a fragment of the Old Town in Cracow, which had previously been covered by classical surveying. Based on the national geodetic control points and in relation to the National Spatial Reference System, with reference to GNSS, surveys of buildings arranged in a compact development were performed with a terrestrial laser scanner in order to compare the accuracy of determining real estate boundaries using these two methods. Possibilities of collecting data on the developed real properties that could be incorporated into the 3D cadastre in the future were identified and the quality of the obtained information was rated.
\end{abstract}

Key words: sources of information on real estate, land management, cadaster.

JEL Classification: R52, O32.

Citation: Kwartnik-Pruc A., 2015, Possibilities of Using Innovative Sources of Information on Real Estate in the Spatial Data Collection Process, Real Estate Management and Valuation, Vol. 23, No. 1, pp. 103-113.

DOI: $10.1515 /$ remav-2015-0010

\section{Introduction}

The register of land and buildings is an essential source of information on real estate. Pursuant to Article 2 Subparagraph 8 of the Law on Geodesy and Cartography, it is the "information system that ensures the capture, update and access, in a uniform manner for the country, to the information on land, buildings and premises, their owners, and any other entities who hold or manage this land, buildings or premises." The use of cadastral data in land management is manifold, starting from spatial planning, through the calculation of taxes, the designation of real estate in land and mortgage registers, and finally, in real estate management.

Records of land in the 60's and 70's were established based on the factual circumstances. Development on the ground, not the legal status of the property, was subject to registration. In 
addition, a direct field measurement determining the entity who held the property was not carried out everywhere. Maps created using photogrammetric methods are also used as record maps and, for a part of the Polish territory, old cadastral maps have been adopted for the purpose of land records. In such cases, the accuracy of determining boundaries of record parcels does not meet the accuracy requirements specified in $\S 82$ of the Regulation on the Register of Land and Buildings (ROZPORZĄDZENIE 2001).

Fundamental changes to running the register of land and buildings were introduced by the Regulation on the Register of Land and Buildings of 1996 (ROZPORZĄDZENIE 1996). Pointing to the most important changes, the definition of a cadastral parcel referring to the definition of real estate contained in Article 46 of the Civil Code (UsTAWA 1964) should be mentioned, which gave rise to the standardization of the cadastre with land and mortgage registers. In addition, it was clearly indicated that the entity entered in the records is the owner, thus ending the entering of property holders into the register of land and buildings. Regulations for recording buildings also appeared in the register for the first time.

In force since 2 June 2001, the new Regulation on the Register of Land and Buildings (ROZPORZĄDZENIE 2001) provided the basis for the comprehensive modernization of land records and for creating the register of buildings and premises from the ground up. New attributes of the data recorded so far are subject to registration, such as the object position data source (ZRD) or boundary point position errors (BPP) in relation to the turning point of the boundary, as well as new data on both entities and objects entered into the register of land and buildings (BYDŁOSZ, BIEDA 2013). On 31 December 2013, a significant amendment to this Regulation entered into force. Emphasis was placed on the possibility of supplying the database of topographic objects specified in Article 4 Paragraph $1 \mathrm{~b}$ of the Law on Geodesy and Cartography (UsTAWA 1989) with data from the cadastre, and on creating a computerized cadastral database. To make this possible, however, it is necessary to conduct comprehensive modernization of land records in Poland, so that the position of the turning points of boundaries of cadastral parcels corresponded to the accuracy requirements set forth in the Regulation on Technical Standards for Performing Geodetic Detailed Measurements, and the Preparation and Delivery of These Measurement Results to the National Geodetic and Cartographic Resource Database (ROZPORZĄDZENIE 2011). The correct determination of the boundaries of real estate, in accordance with its legal status, is of crucial importance in the process of real estate management. This has a direct impact on the surface and value of the registered property.

Data necessary to identify the position of the boundaries of cadastral parcels are captured from surveying documentation accepted into the National Geodetic and Cartographic Resource database (\$36 ROZPORZĄDZENIE 2001). If there is no such documentation or the data contained therein are not reliable, the data on the course of the boundaries of parcels are captured by field surveys or photogrammetric surveys, preceded by determining the course of these boundaries. One of the modern methods of taking field measurements, which is becoming widely used, is laser scanning. The method of laser scanning enables to capture spatial data on the studied object. The scope of the application of this method is very wide. It is used to measure a variety of engineering structures and constructions (GAWAEKIEWICZ 2007, 2008, TANG et al. 2010, OWERKO et al. 2012), archaeological objects (LERMAA et al. 2010), and even environmental ones (HEŁDAK et al. 2012, KWARTNIK-PRUC et al. 2013), in order to obtain information about their geometry and, by periodically repeating the measurements, also of the changes that occur in them (OSTROWSKI, MATWIJ 2013). The amendment to the Regulation on the Register of Land and Buildings takes into account the use of modern technology for field measurements.

This article analyzes the rules for determining the turning points of boundaries of cadastral parcels and the accuracy requirements for determining their positions, and then checks whether the method of laser scanning could be used for field measurements in the modernization of the cadastre. While using this method of measurement, it is also possible to capture additional information used in the future to supply the cadastral database regarding buildings and premises, and the creation of the 3D cadastre. Polish literature (DAWIDOWICZ, ŹRÓBEK 2011, BYDŁOSZ 2012, KARABIN 2012) and international sources (DÖNER 2010, AIEN et al. 2013) have, more and more often, been indicating the need for a 3D cadastre. One of the main reasons is the need to record additional spatial information on real estate (PARZYCH et al. 2013, PAULSSON, PAASCH 2013). Problems in determining boundaries and the types of rights to space, which arise in connection with the construction of complex architectural objects, are also indicated (SHOJAEI et al. 2013, AIEN et al. 2013). 


\section{Determining the position of the boundary points of a parcel in the process of modernizing land records}

The amended Regulation on the Register of Land and Buildings (ROZPORZĄDZENIE 2001) assumes that modernization of the records will be carried out in a planned manner, ensuring the creation of a computer database of records by 31 December 2014 for urban areas, and by 31 December 2016 for rural areas. These deadlines are very short. The application of modern surveying techniques may be helpful in meeting them.

The course of the boundaries of cadastral parcels is presented in the records on the basis of surveying documentation accepted into the National Geodetic and Cartographic Resource database and prepared:

1) in delimitation proceedings,

2) for the subdivision of real estate,

3) in consolidation proceedings and land exchange,

4) in proceedings for the consolidation and subdivision of property,

5) for the purposes of judicial or administrative proceedings, and then used for the final judgment or final administrative decision,

6) for establishing, under the previous legislation, the real estate cadastre and the register of land and buildings,

7) by the National Border Guard, if this documentation defines the course of state boundaries with an accuracy that is appropriate for the records,

8 ) as a result of detailed surveying of the existing or restored boundary markers or determined boundary points.

The above list has been expanded to include sections 7 and 8 as part of the Amendment of 2013. The last point appeared in this Regulation as a consequence of the provisions contained in the Regulation on Technical Standards for Performing Geodetic Detailed Measurements and the Preparation and Delivery of These Measurement Results to the National Geodetic and Cartographic Resource Database (ROZPORZĄDZENIE 2011). The provisions of this Regulation require surveyors to possess level 1 professional qualifications (detailed measurements, setting out measurements and asbuilt measurements) to determine the boundaries of real estate when preparing maps for design purposes when the subject of the planned investment are buildings placed at a distance of not more than $4.0 \mathrm{~m}$ from the boundary of the real property, while in the National Geodetic and Cartographic Resource database there are no available data determining the position of boundary points with the required accuracy. So far, surveyors with these types of professional qualifications were not allowed to carry out this kind of work; therefore, to start off with, the necessity for cooperation between surveyors holding level 1 and 2 professional qualifications was established, or making it mandatory for the surveyor preparing the map for design purposes to possess both of these qualifications. Due to the signaled doubts, the Head Office of Geodesy and Cartography posted an explanation on 31 August 2012, which stated that geodetic detailed measurements of the objects included in the register of land and buildings, including boundary markers and points, as well as of the buildings, can be carried out by surveyors having professional level 1 qualifications. The same held true for restoring and determining boundary points and determining the course of cadastral parcel boundaries, which should be treated as operations aimed at identifying the location of boundary points in the field.

If there is no documentation defining the course of the boundaries of cadastral parcels, or if the data contained therein are not reliable, data on the course of such boundaries are captured by means of field surveys or photogrammetric surveys, preceded by the determination of the course of these boundaries. According to the amended wording of the Regulation (ROZPORZĄDZENIE 2001), the procedure of determining the boundaries of record parcels, including the position of the boundary points defining them, is performed by an authorized surveyor on the basis of consistent statements of the owners or perpetual users of these parcels, or the holders of these parcels subject to autonomous possession, confirmed by their consistent declaration made to the protocol of determining the course of the boundaries of these cadastral parcels.

This Regulation raises serious doubts, as it allows for the formalization of the factual circumstances that may be inconsistent with the legal status of the property. However, this applies only to situations when both parties unanimously and consistently specify the course of the boundary. If the existing status in the field lasts for many years and it is fully accepted by the parties, entering it into the 
documentation eliminates unnecessary boundary disputes. It seems necessary, however, to set forth in the Regulation an acceptable discrepancy between the status in the documentation and the one specified by the parties. Only in the event of a dispute regarding the parcel boundaries does the Regulation require conducting an analysis of the available documents defining the legal status of land within the boundaries of these parcels, verifying boundary markers and traces, and carrying out an analysis of all available documents containing information relevant in this regard, including statements of the involved entities and witnesses.

The data regarding the position of boundary points is not limited only to the coordinates. The Regulation on the Register of Land and Buildings (ROZPORZĄDZENIE 2001) introduced an obligation to record additional attributes such as:

- boundary point position data source (ZRD),

- boundary point position error (BPP),

- boundary point stability code (STB),

- boundary category code (RZG).

These attributes were subject to significant modification as of 31 December 2013. The attribute object position data source - clarified the methods of determining the position of a boundary point and was supplemented by the vectorization of cartographic studies other than the cadastral map. For example, prior to 31 December 2013, an attribute with the value of 1 was used in a situation where the information on the boundary point position was captured from field surveys preceded by the determination of the boundary course, though the method of determining this boundary was not specified. Currently, attribute 1 is assigned to a boundary point whose position was determined in field surveys preceded by the delimitation of real estate, restoration of boundary markers, determination of boundary points or determination of their position in a different mode. Unfortunately, different types of proceedings aimed at determining the position of boundary points, which affect the legal status of a boundary in various ways, were combined into one whole (HYCNER et al. 2013, KWARTNIK-PRUC 2013). This is not a proper solution. Boundary points that represent an invariable and permanent legal boundary should be recorded separately. The current list of values for this attribute has been presented in Table 1 .

Table 1

Attribute values - boundary point position data source

\begin{tabular}{|c|c|}
\hline $\begin{array}{l}\text { Attribute } \\
\text { value }\end{array}$ & Boundary point position data source \\
\hline 1 & $\begin{array}{c}\text { Field surveys preceded by the delimitation of real estate, restoration of boundary } \\
\text { markers, determination of boundary points or determination of their position in a } \\
\text { different mode }\end{array}$ \\
\hline 2 & $\begin{array}{c}\text { Field surveys not preceded by the delimitation of real estate, restoration of } \\
\text { boundary markers, determination of boundary points or determination of their } \\
\text { position in a different mode }\end{array}$ \\
\hline 3 & $\begin{array}{l}\text { Photogrammetric surveys preceded by the determination of cadastral parcel } \\
\text { boundaries and their signaling, or photogrammetric surveys of unambiguously } \\
\text { identified boundary points, previously determined as provided by law }\end{array}$ \\
\hline 4 & $\begin{array}{c}\text { Photogrammetric surveys not preceded by the determination of cadastral parcel } \\
\text { boundaries and their signaling }\end{array}$ \\
\hline 5 & $\begin{array}{l}\text { Approved projects of real estate subdivision, or of real estate consolidation and } \\
\text { subdivision }\end{array}$ \\
\hline 6 & Approved projects of land consolidation or exchange \\
\hline 7 & $\begin{array}{c}\text { Screen vectorization of raster cadastral map while using the results of field surveys } \\
\text { (linear measurements) }\end{array}$ \\
\hline 8 & $\begin{array}{l}\text { Screen vectorization of raster cadastral map without using the results of field } \\
\text { surveys }\end{array}$ \\
\hline 9 & Screen vectorization of cartographic studies other than the cadastral map \\
\hline
\end{tabular}

Source: ROZPORZĄDZENIE (2001). 
The attribute - boundary point position error - has changed its name and definition. It is currently the mean error of boundary point position relative to the class 1 geodetic control. The values and ranges of this attribute have not changed (Table 2).

Table 2

Attribute values - mean error of boundary point position relative to class 1 geodetic control

\begin{tabular}{|c|c|}
\hline Attribute value & $\begin{array}{c}\text { Mean error of boundary point position relative to } \\
\text { class 1 geodetic control }\end{array}$ \\
\hline 1 & $0.00-0.10 \mathrm{~m}$ \\
\hline 2 & $0.11-0.30 \mathrm{~m}$ \\
\hline 3 & $0.31-0.60 \mathrm{~m}$ \\
\hline 4 & $0.61-1.50 \mathrm{~m}$ \\
\hline 5 & $0.61-1.50 \mathrm{~m}$ \\
\hline 6 & above $3.00 \mathrm{~m}$ \\
\hline
\end{tabular}

Source: ROZPORZĄDZENIE (2001).

The reference point has been subject to a fundamental change. In the original version it was a position error relative to the control - understood as the measurement control. Consequently, a direct measurement of the boundary point as a field detail of the $1^{\text {st }}$ class of accuracy was carried out with an accuracy of at least of $0.10 \mathrm{~m}$, and such a point was assigned a BPP attribute of the value of 1 . Currently, the mean error of boundary point position is to be determined in relation to the class 1 geodetic control. Assuming nominal errors of position of the national control points, the propagation of errors results in no boundary point determined by classic methods of surveying based on the measurement control obtaining the attribute value of 1 . While the error of the positioning of the control points can be calculated in the process of its alignment, the errors of class 2 and class 3 geodetic controls are not provided in the topographical descriptions made available by geodetic and cartographic documentation centers. The introduced change aims to include the boundary points measured by the RTK GPS method of surveying in the database of land records. It also concerns the situation of establishing a measurement control to capture data on boundary points using GNSS surveying technology, based on the national network of reference stations ASG-EUPOS. The application of these new technologies allows for the actual determination of the mean error of boundary point position relative to the class 1 geodetic control, which may be less than $0.10 \mathrm{~m}$. The stability codes have not changed. The boundary category codes have been extended from 6 to 7 elements by the boundary of the gmina, according to the cadastral unit. This is reasonable, because the boundary of a gmina is not always consistent with the boundary of a cadastral unit, especially in cities.

\section{Attributes of buildings and premises as subjects of the register of land and buildings possible to capture from field surveys}

The Regulation on the Register of Land and Buildings (ROZPORZĄDZENIE 2001) specifies in detail the cadastral data recorded for buildings or premises. The amendment of 2013 has even expanded the scope of the recorded information. The majority of these data, however, are not captured by surveying but result from construction documents - for example, a construction project, documents from the administrative procedure for a building permit, or an occupancy permit. These include: the status of a building, the function of a building, completion date of construction, or building class according to the Polish Classification of Types of Constructions. For example, an obligation was introduced to record the number of apartments according to the construction documents in a residential building, divided into apartments consisting of 1 to 10 rooms, or larger. The Starost's responsibility to run the register of land and buildings is a government task in the scope of geodesy and cartography. In this public register, the recording of data processed by architectural and construction authorities should be conducted in close cooperation, with an obligatory specification of the bodies responsible for the implementation of specific data, or at least preparing and making them available, which was only partially set out in the Regulation.

Surveying data regarding the buildings which are recorded in the register of land and buildings include: 
1) a numerical description of the outline of the building,

2) footprint area of the structure.

The building outline is understood as a closed line defined by a rectangular projection on the horizontal plane of the line where the external walls of a building intersect the ground surface. In the case where the building foundation intersects with the ground surface, or the building is constructed on pillars, the outline of the building is a line which is determined by a rectangular projection on the horizontal plane of the line where the outer edges of the foundation, or the outer edges of the pillars, intersect with the ground surface. If the rectangular projections of the outer walls of the above-ground or underground stories on the horizontal plane are not consistent with the outline of the building, or if adjacent buildings are connected by above-ground or underground connectors, these stories and connectors are specified in the cadastral database as blocks of the building, using a numerical description.

The data on the building outline may be supplemented by:

1) digital photographs of buildings,

2) data defining the position of the geometric center of a building in the 2000 system.

The footprint is understood as the surface area of a geometric figure defined by the outline of a building. The cadastral database, in addition to the outline of a building and its blocks, may include building structures which are permanently attached to it, such as: a patio, porch, hall, stairs, support, ramp, entrance to the underground level, wheelchair ramp.

As part of the field inspection or field measurements, it is also possible to determine:

1) the main function of a building and its other functions,

2) information on the material used to build the exterior walls of a building,

3) the number of above-ground and underground stories of a building.

In relation to flats, information is captured almost entirely from the building design and construction documentation. During field inspection, it is only possible to define which story the main entrance to the flats is on.

\section{Description of field research}

The purpose of the field research was to check whether it is possible to use laser scanning technology to capture information on the course of property boundaries in areas with compact development. It was assumed that the turning points of cadastral parcels in the object specified for comparison should be determined in a direct measurement, with the $1^{\text {st }}$ class of accuracy for field details, which include boundary points and markers, in accordance with $\S 28$ of the Regulation of the Minister of Internal Affairs and Administration of 9 November 2011 on Technical Standards for Performing Geodetic Detailed Measurements and the Preparation and Delivery of These Measurement Results to the National Geodetic and Cartographic Resource Database (ROZPORZĄDZENIE 2011).

A fragment of Grodzka Street in Krakow, from All Saints Square to the Main Market Square, was selected as the subject of the research. In the years 2008-2009, this area was subjected to modernization of the land and buildings register survey, along with the establishment of a register of buildings and premises. The turning point coordinates of the boundaries were determined based on the results of a direct measurement with classic surveying methods. Class 3 national control points located in the vicinity were used. These data were captured from the municipal Geodetic Documentation Center database in Cracow. The measurement was carried out in December 2013, in snowfree weather. Two points of the class 3 state control were used directly during the field work. The coordinates of these points were captured from the municipal Geodetic Documentation Center database. The scanning reference points were measured by the tacheometric method of surveying, using Leica $1102+$. In order to verify the coordinates of the national control points and to determine the actual boundary point position error, an independent, static GNSS survey of these points was performed, using Leica GPS1200 receivers, based on the national network of reference stations - ASG-EUPOS. A Leica ScanStation C10 scanner was used for the scanning survey. The measurement was performed at four positions.

The study area is located in one of the busiest areas of Krakow. Therefore, it was decided to conduct the surveys at night, so as to reduce the number of objects obscuring the buildings to a minimum. The assumption proved to be well-founded. The survey of the control along with the scanning surveys at four positions lasted about 5 hours. A light drizzle on that night resulted in the 
occurrence of some points which were not representative of the existing structures. Such disturbances may, however, be eliminated in the process of data assessment.

\section{Assessment of the measurement results}

Assessment of the measurement results was carried out in two ways. First of all, an analysis was performed based on the national control captured from the geodetic documentation center database. The coordinates of the scanning reflective targets were determined based on this control in the GEONET program. The measurement accuracy of the reflective targets was performed at $3-4 \mathrm{~mm}$ relative to the control.

Secondly, the relation of the entire measurement network to the National Spatial Reference System was adopted using GNSS referencing. The coordinates of the control points measured by the static GNSS method were calculated in the Leica Geo Office software. The observations were tied to the permanently operating reference station KRA1, which is a part of the ASG-EUPOS system. Tachometric measurements were calculated in the GEONET program to obtain maximum positioning errors of the scanning control points at the level of $5 \mathrm{~mm}$.

Having calculated the coordinates of the scanning control in two sets, the results of the scanning measurements were then assessed using the Leica Cyclone program. Two files were prepared with a list of the coordinates of the scanning targets, which were used to automatically load the data on the control to the program. A new database was created and point clouds measured at different positions were entered. Then, using the files with the scanning control coordinates, they were automatically connected twice, independently, on the basis of the reflective targets illustrated on the scans. In most cases, the target centers were detected correctly. The analysis of the obtained residuals allowed to verify the identification of the two targets and to indicate their center manually. Centers of the targets which were scanned at acute angles to the line of sight of the scanner were determined erroneously. The maximum error of fitting the target for the scanning control calculated based on the coordinates of the national control was $7 \mathrm{~mm}$, while for the control aligned based on the ASG-EUPOS system - $5 \mathrm{~mm}$. A fragment of the connected point clouds has been presented in Figure 1.

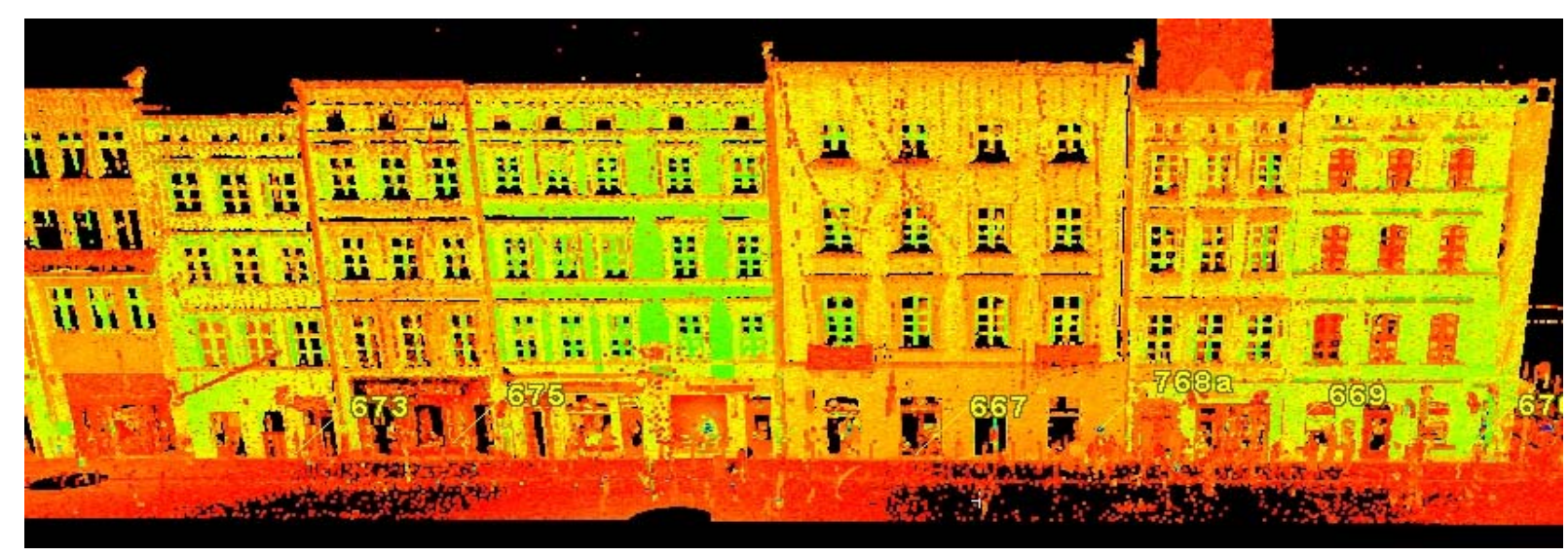

Fig. 1. Fragment of the connected point clouds. Source: own research.

The main task, however, was to determine the position of the turning points of cadastral parcel boundaries. For this purpose, the modeling available in the Leica Cyclone program was used. The section of the plane was determined for the individual turning points of boundaries (Fig. 2).

Then, a horizontal section through the point cloud was conducted and the straight lines were fitted along the walls of the buildings. The points where these lines intersect correspond to the turning point of the boundaries of the built-up real properties. In this way, two separate sets of coordinates of 30 turning points were established, which were tied directly to the national control and the National Spatial Reference System, based on reference to the ASG-EUPOS network.

A problem that occurred at the stage of scanning data analysis was the correct identification of the corner of the building, which corresponded to the turning point of the plot boundary on the scan. It was not always possible to correctly identify the end of a building on the basis of a point cloud. Very often, the problem was connected with rain pipes, which obscured the corners of the buildings. In this type of work, a thorough field inspection proved to be particularly important. Point cloud modeling, 
which is available in the Leica Cyclone program, also proved to be helpful. It was possible to interpolate the course of building walls that were partially obscured by rain pipes, taking two days to assess these data.

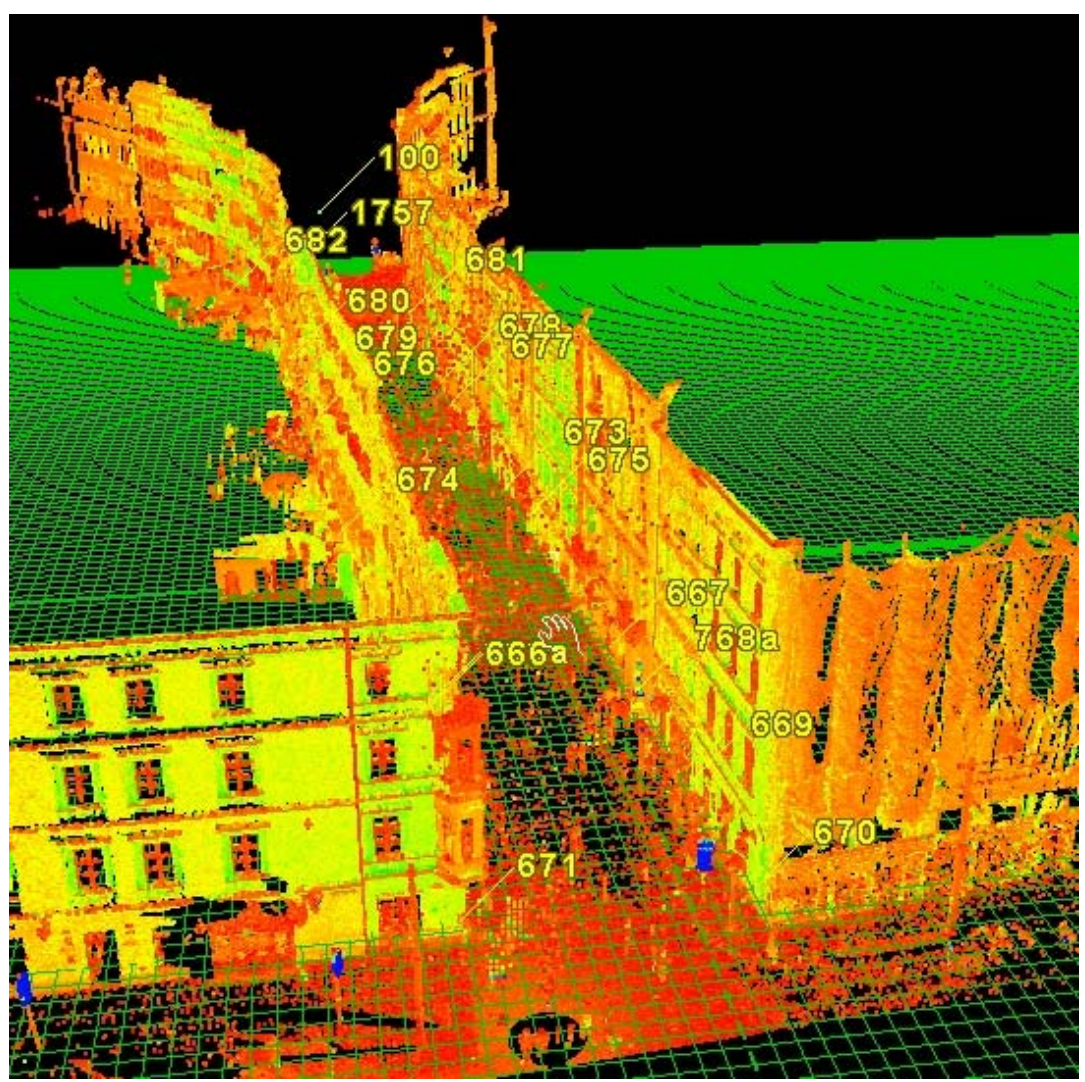

Fig. 2. Determined section of the plane in the Leica Cyclone program. Source: own research.

\section{Evaluation of the research results}

As a result of the analysis of the measurement data, rectangular coordinates of the boundary points were determined in the National Spatial Reference System by reference to the ASG EUPOS network $x^{G N S S} x^{\text {GNSS }}$ and $y^{G N S S} y^{\text {GNSS }}$, and by reference to the points of the national geodetic control $-x^{\text {OSN }}$

$x^{\mathbf{O S N}}$ and $y^{O S N} y^{\mathrm{OSN}}$. In order to assess the usefulness of terrestrial laser scanning technology to capture cadastral data, the coordinates of the boundary points obtained from the performed research were compared to the coordinates entered into the register of land and buildings. Then, the differences between their values were calculated as:

$$
\delta_{x_{i}}^{G N S S}=x_{i}^{E G i B}-x_{i}^{G N S S}, \delta_{y_{i}}^{G N S S}=y_{i}^{E G i B}-y_{i}^{G N S S} \text { and } \delta_{x_{i}}^{O S N}=x_{i}^{E G i B}-x_{i}^{O S N}, \delta_{y_{i}}^{O S N}=y_{i}^{E G i B}-y_{i}^{O S N} .
$$

On the basis of the calculated differences, parameters for assessing the accuracy were determined, among which the most important is the sample standard deviation:

where $\mathrm{n}$ - sample size.

$$
s=\sqrt{\frac{\sum_{i=1}^{n} \delta_{i}^{2}}{n-1}}
$$

Another measure of diversity, more resistant to outliers, is the mean deviation:

Maximum deviation:

$$
D=\frac{\sum_{i=1}^{n}\left|\delta_{i}\right|}{n} .
$$

$$
\delta_{\max }=\max \left|\delta_{i}\right| .
$$


may indicate the existence of outliers. Systematic error will appear when the value of the mean deviation $\delta_{s r} \delta_{s}$ r is different from zero:

$$
\delta_{s r}=\frac{\sum_{i=1}^{n} \delta_{i}}{n} .
$$

The obtained accuracy parameters have been summarized in Table 3.

Table 3

Results of evaluating the measurement accuracy of the coordinates of boundary points

\begin{tabular}{|l|l|l|l|l|}
\hline & \multicolumn{2}{l|}{$\begin{array}{l}\text { Reference to the } \\
\text { ASG-EUPOS network }\end{array}$} & \multicolumn{2}{l|}{$\begin{array}{l}\text { Reference to the points of } \\
\text { geodetic control }\end{array}$} \\
\hline & $x^{\text {GNSS }}$ & $y^{\text {GNSS }}$ & $x^{\text {OSN }}$ & $y^{\text {OSN }}$ \\
\hline Sample size & 30 & 30 & 30 & 30 \\
\hline Standard deviation, $s$ & $39 \mathrm{~mm}$ & $38 \mathrm{~mm}$ & $45 \mathrm{~mm}$ & $41 \mathrm{~mm}$ \\
\hline Mean deviation, $D$ & $28 \mathrm{~mm}$ & $24 \mathrm{~mm}$ & $34 \mathrm{~mm}$ & $25 \mathrm{~mm}$ \\
\hline Maximum deviation, $\delta_{\max } \delta_{\max }$ & $87 \mathrm{~mm}$ & $141 \mathrm{~mm}$ & $113 \mathrm{~mm}$ & $154 \mathrm{~mm}$ \\
\hline Mean value of the deviaton, $\delta_{s r} \delta_{s} \mathbf{r}$ & $8 \mathrm{~mm}$ & $1 \mathrm{~mm}$ & $6 \mathrm{~mm}$ & $10 \mathrm{~mm}$ \\
\hline
\end{tabular}

Source: own research.

\section{Conclusions}

Technical standards, both those in force in the past and currently binding ones (ROZPORZĄDZENIE 2011), allow the application of modern methods, technologies and measurement techniques when conducting surveys as long as they ensure that observational data is captured with the required accuracy. Although the land register covers the entire territory of Poland, the quality of information on the position of boundary turning points often does not meet the required accuracy standards (HANUS 2013). This has a direct, and often adverse, effect on real estate management. Terrestrial laser scanning technology is among those innovative technologies for which no precise accuracy requirements have been determined, neither regarding the control network nor the implementation of the measurement itself.

Having captured the Cartesian coordinates of the boundary points from scanning data analysis, they were compared to the nominal coordinates captured from the geodetic documentation center database. Values of standard deviation at a level of 38-45 mm means that the accuracy of positioning boundary points by the terrestrial scanning method meets the requirements set for field details of the $1^{\text {st }}$ class of accuracy. Taking into account the accuracy of the control network, one can also say that the condition of determining the position of boundary points with a mean error not exceeding $0.30 \mathrm{~m}$ relative to the class 1 geodetic control has been met (ROZPORZĄDZENIE 2001). Although the maximum deviation, $\delta_{\max }$ reaching $\pm 154 \mathrm{~mm}$, should be mentioned, differences exceeding $0.10 \mathrm{~m}$ refer to only two boundary points. The last amendment to the Regulation on the Register of Land and Buildings (ROZPORZĄDZENIE 2001) indicated consistent joint declaration of parties as the basis for determining the boundaries of cadastral parcels in the modernization process. In the case of compact development, as in the study area, such a solution seems reasonable, even if not all the boundary points reach the required accuracy.

As a result of the scanning measurement, data on the spatial location, shape and dimensions of buildings and other elements of the development are captured. The coordinates of the body of the building can be specified with an accuracy of $1^{\text {st }}$ class details. We obtain information on the shape of the facade, as well as the location and number of windows on each floor. We are familiar with the height and pitch of the roof. On this basis, it is possible to verify information recorded in the register of land and buildings, such as: the footprint area or the number of stories. Such detailed information can be used in the future to create a 3D cadastre. According to Karabin (2012), the essence of the 3D cadastre is to record the third dimension, so that, in addition to the cadastral parcel boundaries in the horizontal plane, it is also possible to record the vertical boundaries. This will make it possible to record rights to space both above the ground as well as below it. Such a need has derived from 
practice. More and more often, underground and above-ground objects are implemented along with buildings erected on the ground. Of course, the spatial restriction of property rights must be governed by the provisions of an act of law; however, with the ever increasing value of property, especially in urban areas, such legislative solutions appear necessary. Thus, information captured from laser scanning will allow the spatial extent of an object to be unambiguously determined and its full 3D visualization to be realized based on geodetic coordinates. Based on these data, with the support of the technical documentation created in connection with separating an apartment, it will also be possible to spatially determine the location of such premises in a building and to implement the 3D visualization of its location within it.

The study has been carried out with financial support from statutory research fund No. 11.11.150.005 AGH University of Science and Technology.

\section{References}

AiEn A., KalANTARi M., RAJABifard A., WilliamsOn I., WALLACE J., 2013, Towars Integration of 3D Legal and Physical Objects in Cadastral Data Models, Land Use Policy, Vol. 35, pp. 140-154.

ByDŁosz J., 2012, The Cadastre in Poland - The Current Status and Possibilities of Transformation into 3D One, FIG Working Week 2012, Italy, http://www.gdmc.nl/3DCadastres/literature/3Dcad_2012_11.pdf, 13.01.2014

BYDŁOSZ J., BIEDA A., 2013, New Regulations for Building Information Infrastructure in Poland, Proceedings International Conference SDI \& SIM 2013, Skopje, pp. 31-41.

DAWIDOWICZ A., ŹRÓBEK R.,2011, Ewolucja potencjału systemu katastru nieruchomości w Polsce w świetle zatożen Międzynarodowej Federacji Geodetów (FIG) (The Evolving Role of the Polish Cadastral System in the Light of the Assumptions of the International Federation of Surveyors (FIG)), Studia i Materiały Towarzystwa Naukowego Nieruchomości, Vol. 19, No. 4, pp. 55-69.

DÖNER F., THOMPSON R., STOTER J., LeMmen Ch., Ploeger H., VAN OOSTEROM P., ZlatanOVa S., 2010, 4D Cadastres: First Analysis of Legal, Organizational, and Technical Impact - With a Case Study on Utility Networks, Land Use Policy, No. 27, pp. 1068-1081.

GAWAŁKIEWICZ R., 2007, Przyktad zastosowania skaningu laserowego w inwentaryzacji i monitoringu wysokich obiektów przemystowych (Example of Applying Laser Scanning in Inventory and Monitoring of High Industrial Objects), Geomatics and Environmental Engineering, Vol. 1, No. 4, pp. 111-126.

GAWAŁKIEWICZ R., 2008, Skanowanie laserowe w monitoringu obiektów powłokowych (Laser scanning in the monitoring of shell structures), Przegląd Budowlany, No. 2, pp. 40-44.

HANUS P., 2013, Correction of Location of Boundaries in Cadastre Modernization Process, Geodesy and Cartography, Vol. 62, No. 1, pp. 51-65.

HYCNER R., HANUS P., KWARTNIK-PRUC A., 2013, Analiza terminologiczna wybranych problemów katastru i zagadnień pokrewnych. Cz. 1, Dziatka, granica, nieruchomość (Terminological Analysis of Selected Problems of the Cadastre and Related Subjects. Part 1, Lot, Boundary, Real Estate), Geodeta: magazyn geoinformacyjny, No. 10, pp. 15-22.

HęDAK M., SzCZEPAŃSKI J., PATRZAŁeK C., 2012. Using the 3D Computer Scanning Method in the Environmental Impact Assessment. Infrastruktura i Ekologia Terenów Wiejskich, Vol. 1, No. 4, pp. 4959.

KARABIN M., 2012, Registration of Untypical 3D Objects in Polish Cadastre - Do We Need 3D Cadastre?, Geodesy and Cartography, Polish Academy of Sciences, Vol. 61, No. 2, pp. 75-89.

KONIECZNA J., TRYSTUŁA A., 2011, Kataster nieruchomości jako podstawa systemu informacji przestrzennej wspomagającego gospodarowanie nieruchomościami (The Cadastre as a Basis of the Spatial Information System Supporting Real Estate), Studia i Materiały Towarzystwa Naukowego Nieruchomości - Vol. 19, No. 4, pp. 33-43.

KWARTNIK-PrUC A., 2013, Assessment of Procedures for Determining Property Boundaries in the Context of Creating Cadastre in Poland, International Multidisciplinary Scientific GeoConference SGEM, GeoConference on Informatics, Geoinformatics and Remote Sensing, conference proceedings; Vol. 2, Geodesy and Mine surveying; Photogrammetry and Remote sensing, pp. 71-78.

KwartniK-Pruc A., KuRAs P., Kocierz R., OrTYL Ł., Owerko T., 2013, The Possibility of Using Remote Sensing Techniques in Geometric Surveying of Caves, International Multidisciplinary Scientific GeoConference SGEM, GeoConference on Informatics, Geoinformatics and Remote Sensing, conference proceedings; Vol. 2, Geodesy and Mine Surveying; Photogrammetry and Remote Sensing, pp. 479-486. 
LermaA J.L., NAVARRoA S., CABrellesA M., VillaVerdeB V., 2010, Terrestrial Laser Scanning and Close Range Photogrammetry for 3D Archaeological Documentation: The Upper Palaeolithic Cave of Parpalló as a Case Study, Journal of Archaeological Science, Vol. 37, Issue 3, pp. 499-507.

OstroWSKI J., MATWIJ W., 2013, Zastosowanie naziemnego skaningu laserowego do wyznaczania przemieszczeń $i$ deformacji wiaduktu drogowego na terenie górniczym (Application of Terrestrial Laser Scanning for the Determination of Dislocations and Deformations of a Road Viaduct in a Mining Area), Przegląd Górniczy, Vol. 69, No. 6, pp. 36-43.

OWERKO T., ORTYL Ł, KURAS P., KOCIERZ R., 2012, Wykorzystanie skaningu laserowego do wyznaczania deformacji stalowych wież telekomunikacyjnych (Use of Laser Scanning for Determining the Deformation of Steel Telecommunication Towers), Pomiary, Automatyka, Kontrola, Vol. 58, No. 12, pp. 1087-1090.

PARZYCH P., ŚLIWIŃSKI Ł., BYDŁOSZ J., 2013, 3D Cadastre in Polish Conditions, Proceedings International Conference SDI \& SIM 2013, SKOPJE, pp.13-21.

PAulsSON J., PAASCH J.M., 2013. 3D Property Research from a Legal Perspective, Computers, Environment and Urban System, Vol. 40, pp. 7-13.

ROZPORZĄDZENIE Ministrów Gospodarki Przestrzennej i Budownictwa oraz Rolnictwa i Gospodarki Żywnościowej z dnia 17 grudnia 1996 r. w sprawie ewidencji gruntów i budynków (Regulation of the Ministers of Spatial Economy and Construction, and Agriculture and Food Economics, dated 17 Dec. 1996, on the Register of Land and Buildings), Dz.U. Nr 158, poz. 813 (Journal of Laws, No. 158, item 813).

ROZPORZĄDZENIE Ministra Rozwoju Regionalnego i Budownictwa z dnia 29 marca 2001 r. w sprawie ewidencji gruntów i budynków (Regulation of the Minister of Spatial Economy and Construction, dated 29 March 2001, on the Register of Land and Buildings), Dz. U. Nr 38, poz. 454 (Journal of Laws, No. 38 item 454).

ROZPORZĄDZENIE Ministra Spraw Wewnętrznych i Administracji z dnia 9 listopada 2011 r. w sprawie standardów technicznych wykonywania geodezyjnych pomiarów sytuacyjnych $i$ wysokościowych oraz opracowywania $i$ przekazywania wyników tych pomiarów do państwowego zasobu geodezyjnego $i$ kartograficznego (Regulation of the Minister of Internal Affairs, dated 9 Nov. 2011, on the Technical Standards for Performing Geodetic Detailed Measurements and the Preparation and Delivery of These Measurement Results to the National Geodetic and Cartographic Resource Database), Dz. U. nr 263, poz.1572 (Journal of Laws, No. 263, item 1572).

ShOJAei D., Kalantari M., BishOP I.D., RAJABIFARD A., AIEN A., 2013, Visualization requirements for 3D Cadastral System, Computers, Environment and Urban System, Vol. 41, pp. 39-54.

TANG P., Huber D.,Akinci B., LipMAn R., Lytle A., 2010, Automatic Reconstruction of As-built Building Information Models from Laser-Scanned Point Cloud: A Review of Related Techniques, Automation in Construction, No. 19, pp. 829-843.

UstaWA z dnia 23 kwietnia 1964 r. Kodeks Cywilny (ACT of 23 April 1964, Civil Code) Dz. U. z 2014 r. poz. 121 (Journal of Laws dated 2014, item 121).

UstAWA z dnia 17 maja 1989 r. Prawo geodezyjne i kartograficzne (Act of 17 May 1989 on Geodesy and Cartography) Dz. U. z 2010 r. Nr 193, poz. 1287 z późn. zm. (Journal of Laws dated 2010, No. 193, item 1287 as amended). 